Ann. Biol. anim. Bioch. Biophys., I976, 16 (3), 297-305.

\title{
STUDIES ON THE SIGNIFICANCE OF THE HIGH LEVELS OF FOLLICLE STIMULATING HORMONE FOR FOLLICULAR DEVELOPMENT IN IMMATURE RATS
}

\author{
J. Th. J. UILENBROEK, Els ARENDSEN de WOLFF-EXALTO* \\ and R. WELSCHEN* \\ with the technical assistance of Lily Gribling-Hegge, Mechtilda Debers,
} Carla Simons and P. Kramer

\author{
Department of Endocrinology, Growth and Reproduction, \\ * Department of Anatomy, \\ Faculty of Medicine, \\ Erasmus University, \\ Rotterdam (Netherlands)
}

\section{SUMMARY}

To determine whether the high FSH levels present before day 20 in female rats are of importance for normal follicular development, the effect of depression of FSH levels on numbers of medium and large follicles was studied. Two approaches have been applied : depression of FSH and $\mathrm{LH}$ levels by injection of testosterone propionate (TP) and elimination of circulating FSH by a specific antiserum to $\mathrm{FSH}$.

Injection of $100 \mu \mathrm{g}$ TP at days 5 , I0 and $\mathrm{I}_{5}$ resulted in decreased FSH and LH levels and in decreased numbers of medium and large follicles at days 10,15 and 20 . Additional treatment from day 5 till day 9 with PMSG (5 IU/ro g body weight/day) restored numbers of follicles towards normal at day Io. This finding indicates that the effect of TP on numbers of follicles is mediated by depression of gonadotrophin levels. Furthermore, the amounts of PMSG required to restore normal follicular development indicates that during this part of the immature period more gonadotrophin is required than during any period of the cycle in the adult.

Injection of antiserum to FSH from day 7 till day I I resulted in a decreased number of large follicles on day I2. The same treatment given from day i 1 till day ${ }_{5}$ or from day I 5 till day I9 did not induce this effect, although one injection on day $1 \mathrm{I}$ or day 15 induced atresia in many large follicles one day later. This acute effect seems to be compensated within five days.

The present results support the view that the high gonadotrophin levels (especially FSH) before day 20 are a requirement for normal follicular development. 


\section{INTRODUCTION}

Several authors have reported high levels of follicle-stimulating hormone (FSH) in rats before 20 days of age (OJEDA and RAMIRÉz, I972; KRAGT and DAHLGREN, I972; MEIJS-RoELOFS et al., I973). Luteinizing hormone (LH) levels, although sometimes elevated, are generally low (MEIJS-ROELOFS et al., I973; DöHLER and WUTTKE, 1974). High blood FSH levels in females early in life have also been reported for immature mice (DULLAART et al., I975), foetal guinea pigs (DonovaN et al., I974) and human foetuses (GRUMBACH and KAPLAN, I973). The possible significance of these high FSH levels for ovarian development is still under investigation.

Studies that made use of antiserum against gonadotrophins suggest that the high FSH levels are required for the early development of the follicular population. Results of these experiments, however, are not uniform. Mice injected daily with antiserum against a total gonadotrophin preparation during the first I4 days of life showed partially arrested follicular growth (ESHKOL and LUNENFELD, I972). Superimposed treatment with FSH or HMG restored some of the changes toward normal. In contrast, SchwarTz et al. (I974) did not find any effect on follicles in rats after daily administration of antiserum to FSH or LH between day 5 and $\mathrm{I}_{5}$.

An alternative approach to answer the question might be suppression of gonadotrophin levels by administration of steroid hormones. A single injection of testosterone propionate (TP) in neonatal rats induced a partial reduction of the high FSH concentrations (CHENG and JoHnson, I973-I974; UnENBROEK et al., in press) and also a reduction of numbers of developing follicles (PETERs et al., I970; UILENBROEK et al., in press). However, PETERs et al. (I970) suggest that the reduction of numbers of developing follicles is due to a direct effect of TP on the ovary.

In the present study effects of administration of 'TP and of antiserum to FSH during the immature period on follicular development were reinvestigated.

\section{MATERIALS AND METHODS}

The present study includes two experiments :

I. Determination of effects of TP treatment on gonadotrophin levels and on the follicular population.

2. Determination of effects of antiserum to FSH on the follicular population.

Rats of a Wistar substrain (R-Amsterdam) were used. Each experimental group consisted of pups of various litters.

After experimental manipulation of hormone levels the follicular population was studied as follows : ovaries were fixed in Bouin's solution and sectioned at $7 \mu \mathrm{m}$; serial sections were mounted and stained with haematoxylin and eosin. In every fifth section all follicles with 20 or more granulosa cells at that cross section $(\approx \geqslant 55 \mu \mathrm{m}$ diameter $)$, in which the nucleolus of the oocyte was visible, were counted and classified in various size classes. Follicles with more than 20 granulosa cells represent the beginning stages of follicle growth (PEDersen and Peters, r968). For convenience some classes were taken together resulting in two groups : medium follicles and large follicles, according to the classification of Pedersen and Peters (1968) (medium follicles: types $3^{b}$ and 4 ; large follicles ; types $5^{a}$ till 8 ). Follicles with two or more cells showing pycnosis or rhexis in the granulosa layer were called early atretic. Follicles with more advanced stages of atresia were neglected. 
Statistical analysis of data was performed using Wilcoxon's two-sample test. A difference was considered as significant if the double tail probability was $\leqslant 0.05$.

\section{Experiment I}

In a first series, groups of 4 to 5 rats were killed at various ages up till 35 days. Ovaries were dissected out for histological study of the normal development of the follicular population.

In a second series, rats were injected s.c. on days 5 , ro and $I_{5}$ with roo $\mu \mathrm{g}$ testosterone propionate (TP) in $0.05 \mathrm{ml}$ oil or with oil alone. Autopsy was performed at 10 , 15 or 20 days of age. Blood for FSH and LH determination was collected by decapitation (at Io or I 5 days of age) of from the orbital venous plexus (20 days of age). Serum FSH and LH concentrations were measured by radioimmunoassay as described previously (WELSCHEN et al., 1975) and expressed in ng NIAMDD-rat-FSH/LH RP-r per ml serum. Ovaries were fixed for histological study.

In a third series it was studied whether the effects on numbers of follicles observed after I $00 \mu \mathrm{g}$ TP were due to a direct effect of TP. A group of rats received roo $\mu \mathrm{g}$ TP on day 5 with or without a super-imposed treatment from day 5 till day 9 of pregnant mare serum gonadotrophin (I or 5 IU PMSG per Io g body weight daily). Autopsy was performed at day Io and ovaries were fixed for histological study.

\section{Experiment $I I$}

Groups of 4 to 5 rats were injected i.p. with normal rabbit serum (NRS) or with antiserum to ovine FSH (AOFSH) that was preincubated with NIH-LH-S I6 in order to reduce contaminating antibodies to LH ( $p$ AOFSH). Injections were started at 7, I I or I 5 days of age and given daily. At autopsy, one or five days after the beginning of treatment, ovaries were fixed for histological study of the follicular population.

The AOFSH was raised in rabbits against NIH-FSH-S 9. The ability of this antiserum to bind FSH and LH was tested in vitro with purified ${ }^{125} \mathrm{I}$ labeled rat FSH and $\mathrm{LH}$ preparations (NIAMDD-rat-FSH/LH I-I). AOFSH in a concentration of $I: I$ ooo showed a substantial cross reaction with $\mathrm{LH}$ (table I). The antiserum was therefore preincubated with LH (I95 ng NIH-LH-S 16/ml AOFSH $\mathrm{I}$ :I ooo). This $p$ AOFSH showed binding with rat LH of 2 p. Ioo only.

\section{TABLE I}

Binding of antiserum against ovine FSH (AOFSH) with rat $\mathrm{LH}$ and $\mathrm{FSH}$; effect of preincubation with ovine $L H$

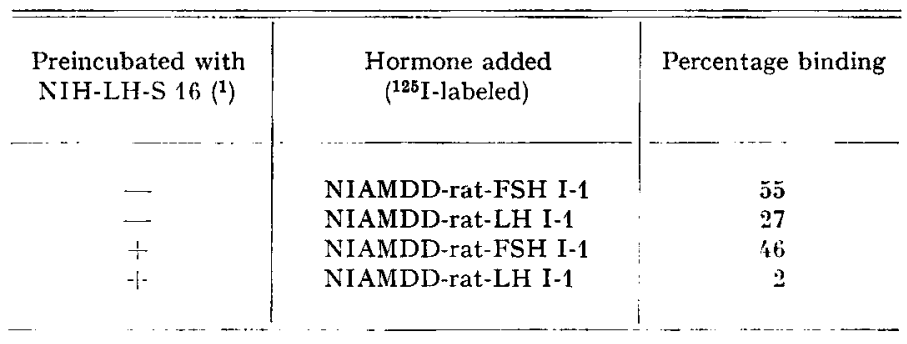

(1) AOFSH was tested in a concentration of 1:1 $000.19 .5 \mathrm{ng}$ NIH-LH-S 16 was incubated with $100 \mu \mathrm{l}$ AOFSH $(1: 1000)$ for $4 \mathrm{~h}$ at room temperature, followed by incubation at $4^{\circ} \mathrm{C}$. for $40 \mathrm{~h}$.

In a pilot study adult rats were injected with $p$ AOFSH at $\mathrm{I} 3.00 \mathrm{~h}$ at prooestrus. At autopsy at oestrus it appeared that $0.02 \mathrm{ml}$ undiluted $p \mathrm{AOFSH} / \mathrm{roo} \mathrm{g}$ body weight caused a significant arrest in follicular growth whereas even after $0.5 \mathrm{ml}$ ovulation was not inhibited. Since FSH levels in early juvenile rats reach values of maximally 3 to 5 times those around ovulation in adults it was decided to use a dose of $0.1 \mathrm{ml}$ undiluted $\mathrm{pAOFSH} / \mathrm{Ioo} \mathrm{g}$ body weight. 
TABI 2

Numbers of follicles (mean \pm SEM) during the prepuberal period in rats of the $R$-Amsterdam strain

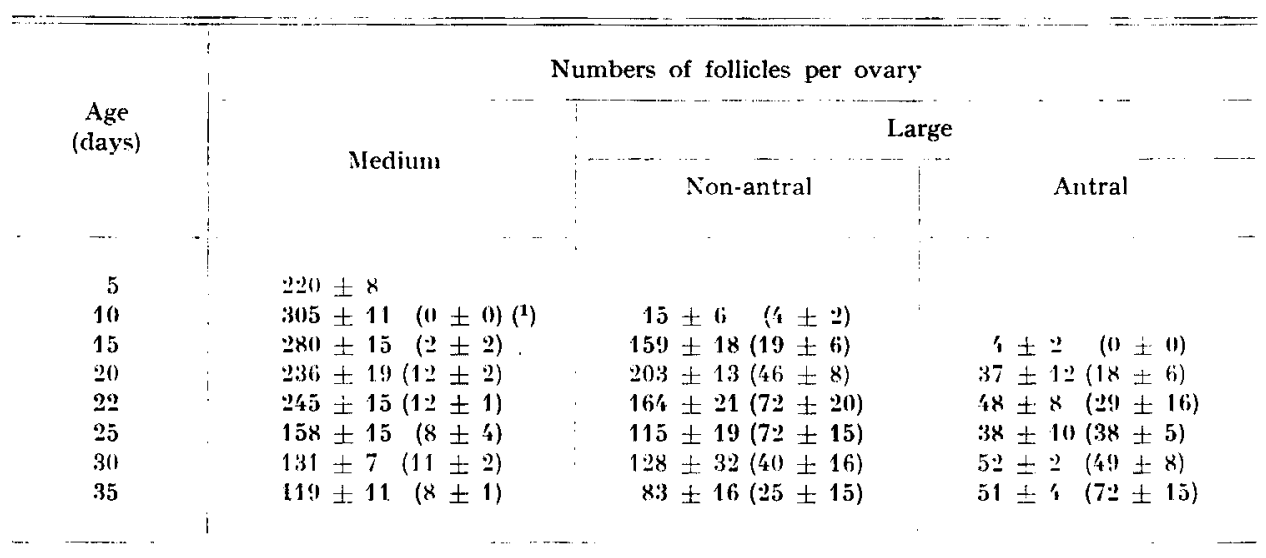

(1) Numbers in parentheses are follicles showing signs of early atresia.

Number of animals 's or 5 .

\section{TABLE 3}

Effects of testosterone propionate (TP) treatment on serum gonadotrophins (mean $\pm \mathrm{SEM}$ ) and number of follicles (mean $\pm \mathrm{SEM}$ ) in immature rats

\begin{tabular}{|c|c|c|c|c|c|c|}
\hline \multicolumn{2}{|c|}{ Treatment } & \multirow{2}{*}{$\begin{array}{l}\text { Autopsy } \\
\text { on day }\end{array}$} & \multirow[b]{2}{*}{ FSH $\left({ }^{1}\right)$} & \multirow[b]{2}{*}{ LH $\left({ }^{2}\right)$} & \multicolumn{2}{|c|}{ Numbers of follicles/ovary } \\
\hline on day(s) & with & & & & medium & large \\
\hline - & - & ! & & & & \\
\hline 5 & oil & 10 & $1408 \pm 111$ & $77 \pm 16$ & $: 270 \pm 15$ & I'́ i \\
\hline 5 & $100 \mu \mathrm{g} T \mathrm{~T}$ & 10 & $286 \pm 2: 3^{*}$ & $<16^{*}$ & $203 \pm 17^{*}$ & $-*$ \\
\hline$\tilde{5}+111$ & oil & 15 & $135 x+75$ & $\because 0 \pm 15$ & $305 \pm 11$ & $9 ! \pm x$ \\
\hline $5+11$ & $100 \mu \mathrm{g} \mathrm{TP}^{\prime}$ & 15 & $313 \pm 97^{*}$ & $<16^{*}$ & $241 \pm \geq 2^{*}$ & $1 * \pm 6 *$ \\
\hline $5+10-15$ & oil & $\dddot{01}$ & $1109 \pm 46$ & $17 \pm 1$ & 246 平 7 & $301 \pm 19$ \\
\hline $5+10 \div 15$ & $100 \mu \mathrm{x}$ TP & 20 & $491 \pm 18 \div *$ & $<8^{*}$ & $196 \pm 14^{*}$ & $151 \pm 18^{*}$ \\
\hline$-\ldots$ & -.-. & - & $\cdots$ & ... & - & $\cdots \quad \ldots$ \\
\hline
\end{tabular}




\section{RESULTS \\ Exp. I : Effects of administration of TP on gonadotrophin levels and on the follicular population}

Series 1.

Mean numbers of medium and large follicles at various ages during the prepuberal period are given in table 2 . The main features are : maximal numbers of healthy follicles at 15,20 and 22 days of age, followed by a decrease in numbers of medium and non-antral large follicles, whereas numbers of antral follicles remained constant ; low frequency of (early) atretic follicles before 20 days of age, followed by a strong increase thereafter. These data obtained in the R-Amsterdam strain are similar to those reported by PEDERSEN (I969) for mice and by de REVIERS (I974) for another Wistar substrain.

\section{Series 2 .}

Data on effects of TP treatment on gonadotrophin levels and on the follicular population are summarized in table 3. At all ages studied TP-treated rats showed significantly lower FSH and $\mathrm{L}_{\mathrm{H}} \mathrm{H}$ levels. FSH levels were still above adult dioestrous values, LH levels were undetectable in all cases. The follicular population showed significantly lower numbers of both medium and large follicles at all ages.

\section{Series 3.}

Mean numbers of follicles in TP-treated rats, given in addition doses of PMSG, are given in table 4. A daily dose of I IU PMSG given per Io $\mathrm{g}$ body weight from day 5 till day 9 increased only the number of medium follicles to values found in oiltreated controls. After daily doses of 5 IU PMSG the number of both medium and large follicles reached control values.

\section{TABLE 4}

Effect of pregnant mare serum gonadotrophin (PMSG) on numbers of follicles (mean $\pm \mathrm{SEM}$ ) in testosterone propionate

(TP)-treated rats

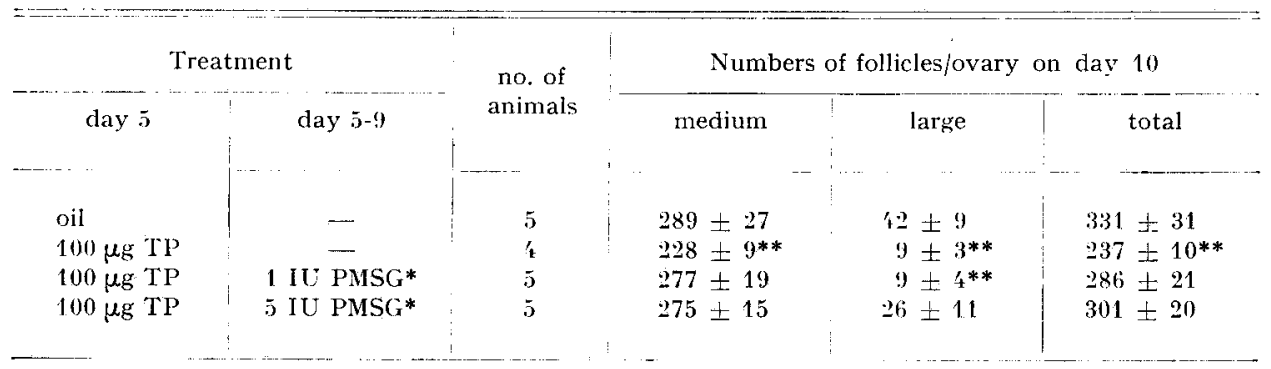

* Given per $10 \mathrm{~g}$ bodyweight and per day.

** Significantly different from oil-treated rats. 


\section{Exp. II : Effects of administration of pAOFSH on the follicular population}

Data are summarized in table 5. Acute effects were observed after injection of pAOFSH at day II or $\mathrm{I}_{5}$ : a significant decrease of the number of large healthy follicles was seen one day later. At that time $p A O F S H$ rats showed many large follicles ( $48 \pm 2$ and $72 \pm \mathbf{I} 2$ on day $\mathbf{I} 2$ and $\mathbf{I} 6$ respectively) with pycnosis or rhexis in the granulosa cells, sometimes in addition to mitoses. These follicles were classified as early atretic. After treatment at day 7 no increase of atresia was observed. On the other hand, five days of treatment resulted in decreased numbers of follicles only when treatment was started at day 7 . This decrease in the number of healthy follicles was not accompanied by increased numbers of atretic follicles.

\section{TABLE 5}

Effect of antiserum against ovine FSH ( $p \mathrm{AOFSH}$ ) on numbers of follicles (mean $\pm \mathrm{SEM}$ ) in immature rats

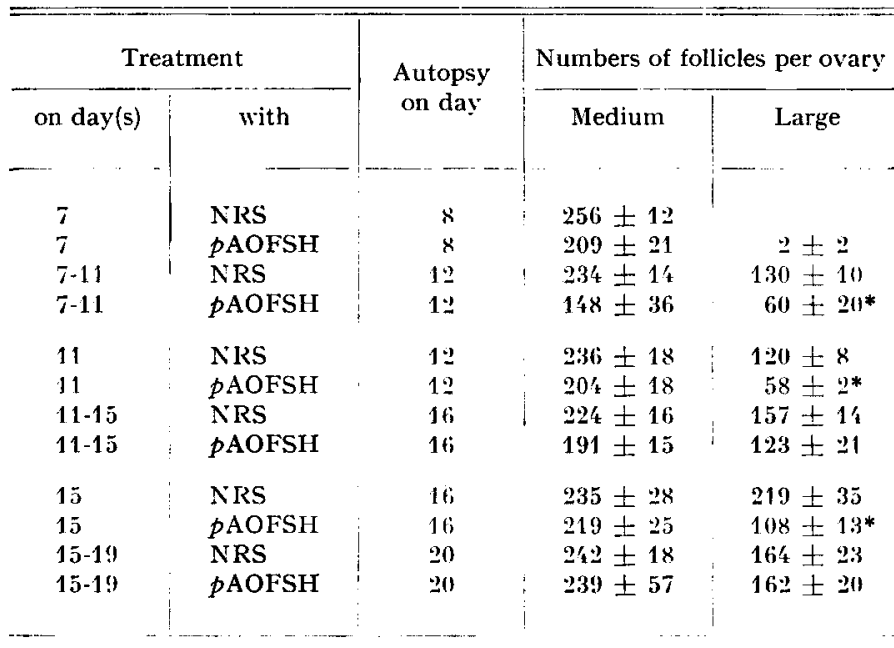

* Significantly different from corresponding NRS-treated rats. Number of animals 4 or 5.

\section{DISCUSSION}

The present experiments indicate that the high gonadotropin levels during the immature period are required for normal follicular growth. After TP treatment both FSH and LH levels were depressed and subnormal numbers of medium and large follicles were observed within five days. Effects of a single injection of TP on numbers of follicles have been described earlier (PETERs et al., I970; UILENBROEK et al., in press). Peters et al. (I970) found a significant decrease in the number of small oocytes within two days and significantly decreased numbers of growing follicles 
three weeks later. Since the number of oocytes is recognized as one of the factors determining the number of developing follicles (KRARUP et al., I969), PETERS et al., suggested that the effect of TP on the ovary could be a direct one. In the present experiments the effects of TP on the follicular population could be overcome by additional administration of PMSG. This finding seems to indicate that the effect of TP on the number of growing follicles is mediated by depressed gonadotrophin levels.

Furthermore, the experiments suggest that during the immature period extremely high levels of gonadotrophins are required for normal follicular growth : FSH levels still considerably above dioestrous values (exp. I, series 2), appeared not sufficient to sustain normal follicular growth. Moreover, substitution with PMSG resulted in restoration of follicular growth only when doses greater than I IU PMSG per Io $g$ body weight were given (exp. I, series 3). WELSCHEN (I973) found that in hypophysectomized adult rats 0.8 IU PMSG per Io $\mathrm{g}$ body weight was sufficient to sustain normal follicular growth from mid-prooestrus to mid-oestrus.

However, since both LH and FSH were depressed in the TP-treated rats no conclusion can be reached with regard to the significance of FSH for follicular growth in immature rats. An attempt to study this problem was made by application of antiserum to FSH. Injection of $p A O F S H$ at day II or $I_{5}$ resulted in atresia of many large follicles one day later, suggesting that these follicles require constant FSH stimulation. Medium follicles seemed more refractory to the atresia-inducing effect of $p$ AOFSH. Administration of pAOFSH daily during five days resulted in decreased numbers of follicles if treatment was started at day 7 . However, treatment starting at days II or I5 was without effect on the numbers of follicles five days later. Treatment with $p$ AOFSH at these later ages apparently induced a shortlasting effect (atresia within $24 \mathrm{hrs}$ ), which compensated during the following days. The compensation might be induced by increased gonadotrophin secretion resulting from decreased steroid secretion by atretic follicles. Evidence for this type of mechanism was provided by KUPPERMAN et al. (1942) who found increased basophilism of the pituitary indicative of increased gonadotrophin secretion - after application of antiserum from day Io till day 20 in rats. Assuming that this mechanism is responsible for the lack of effect of five days pAOFSH treatment from day II or day $I_{5}$ onwards it seems that this mechanism is not fully operative in rats younger than $I 2$ days.

Although the present experiments demonstrate that the approaches used are not fully adequate - TP treatment because of its possible direct effect on the ovary and its action on both FSH and LH; antiserum treatment since the animal seems to be able to secrete compensatory amounts of gonadotrophins - the following conclusions can be reached :

I. Under conditions of subnormal levels of gonadotrophins, especially FSH, less follicles grow either because less follicles start to grow and or because growth rate is retarded.

2. A sudden interruption of FSH stimulation results in atresia of many large follicles.

3. Higher gonadotrophin levels are required to stimulate follicle growth during the immature period than during any phase of the adult cycle. 


\title{
ACKNOWLEDGEMENT
}

The authors are indebted to Dr. J. DullaART for data on specificity of the anti-FSH serum.

\author{
RÉSUMÉ \\ SIGNIFICATION DES HAUTS NIVEAUX D'HORMONE \\ FOLLICULOSTIMUI,ANTE POUR LE DÉVELOPPEMENT FOL_LICULAIRE \\ CHEZ LA RATTE IMMATURE,
}

Les hauts niveaux de FSH présents avant 20 jours chez la Ratte ont-ils une importance pour le développement folliculaire normal ? Pour le savoir, on a étudié l'effet de la réduction des taux de FSH sur le nombre de follicules en croissance moyens et grands. Deux approches ont été choisies : diminution des niveaux de LH et FSH par injection de propionate de testostérone (TP) et suppression de la FSH circulante par un antisérum spécifique de FSH.

L'injection de Ioo $\mu \mathrm{g}$ de TP les jours 5, ro et 15 provoque une diminution des niveaux de LH et FSH et une diminution du nombre de follicules moyens et grands aux jours 10 , 15 et 20 . Un traitement supplémentaire avec PMSG ( $5 \mathrm{IU} /$ ro $\mathrm{g}$ de poids/jour) entre les jours 5 et 9 ramène le nombre de follicules à la normale le jour io. L'effet du TP sur le nombre de follicules passe donc par la diminution du taux de gonadotropines circulantes. En outre, les quantités de PMSG nécessaires pour rétablir un développement folliculaire normal à cette période de la vie sont plus hautes que les quantités requises chez la femelle adulte pendant le cycle.

L'injection d'un sérum anti-FSH entre les jours 7 et I I provoque une diminution du nombre de grands follicules au jour I 2 . Le même traitement entre les jours I I et I 5 ou entre les jours I 5 et I9 est sans effet, bien qu'une injection le jour I I ou le jour I $5_{5}$ induise l'atrésie dans beaucoup de grands follicules un jour plus tard. Cet effet aigu semble être compensé en 5 jours.

Ces résultats montrent qu'un développement folliculaire normal demande des niveaux élevés de gonadotropines (en particulier de FSH) avant 20 jours.

\section{REFERENCES}

Cheng H. C., Johnson D. C., 1973-1974. Serum estrogens and gonadotropins in developing androgenized and normal female rats. Neuroendocrinology, 13, 357-365.

Döhler K. D., WUTTKE W., 1974: Serum LH, FSH, prolactin and progesterone from birth to puberty in female and male rats. Endocrinology, 94, 1003-1008.

Donovan B. T., ter Haar M. B., Lockhart A. N., Peddie M. J., 1975. Changes in the concentration of follicle-stimulating hormone in plasma during development in the guinea-pig. $J$. Endocr., 64, $521-528$.

DUllaART J., Kent J., RYle M., I975. Serum gonadotrophin concentrations in infantile female mice. J. Reprod. Fert., 43, 189-192.

Eshkol A., Lunenfeld B., 1972, Gonadotropic regulation of ovarian development in mice during infancy, 335-346, in : Saxena B. B., Beling C. G., Gandr H. M., Gonadotrophins, Wiley, New York.

Grumbach M. M., Kaplan S. L., I973. Ontogenesis of growth hormone, insulin, prolactin and gonadotropin secretion in the human foetus, 462-487, in : ComLine R. S., CRoss K. W., DAWES G. S., Nathanielsz P. W., Foetal and neonatal physiology, Barcroft Centenary Symposium, Cambridge University Press, Cambridge.

KRAGT C. L., DAHLGREN J., I972. Development of neural regulation of follicle stimulating bormone (FSH) secretion. Neuroendocrinology, 9, 30-40.

Krarup T., Pedersen T., Faber M., 1969. Regulation of oocyte growth in the mouse ovary. Nature, 284, $187-188$. 
Kupperman H.S., Meyer R. K., Finerty J. C., I942. Precocious gonadal development occurring in immature rats following a short-time treatment with antigonadotropic serum. Am. J.Physiol., 136, 293-298.

Meijs-Roelofs H. M. A., Uilenbroek J. Th. J., Osman F., Weischen R., I973. Serum levels of gonadotropins and follicular growth in prepuberal rats. 3-II, in : Peters $\mathrm{H}$., The development and maturation of the ovary and its functions. Excerpta Medica Foundation, Amsterdam.

OJEDA S. R., RAMiréz V. D., I972. Plasma level of LH and FSH in maturing rats : response to hemigonadectomy. Endocrinology, 90, 466-472.

Pedersen T, 1969. Follicle growth in the immature mouse ovary. Acta. Endocr, 62, II 7-132.

Pedersen T., Peters H., rg68. Proposal for a classification of oocytes and follicles in the mouse ovary. J. Reprod. Fert, 17, 555-557.

Perers H., Sørensen I. N., Byskov A. G., Pedersen T., Krarup T., I97o. The development of the mouse ovary after testosterone propionate injection on day $5,35 \mathrm{I}-36 \mathrm{I}$, in : BUTT W. R., CROOKE A. C., RYLE M., Gonadotrophins and ovarian development, Livingstone, Edinburgh.

DE Reviers M. M., I974. Étude quantitative de l'action des hormones gonadotropes hypophysaires sur la population folliculaire de l'ovaire de ratte immature, signification biologique du dosage de l'hormone folliculo-stimulante par le test de Steelman et Pohley. D. Sc. Thesis, University of Tours.

Schwartz N. B., Anderson C. H., Nequin L. G., Ely C. A., i974. Follicular maturation, 36738I, in : Grumbach M. M., Grave G. D., Mayer F. E., The control of the onset of puberty, Wiley, New York.

Uilenbroek J. Th. J., Arenden de Wolff-Exalto E., Blankenstein M. A. ig76. Serum gonadotrophins and follicular development in immature rats after early androgen administration. J. Endocr., 68, (in press).

WELSCHEN R., I973. Amounts of gonadotrophins required for normal follicular growth in hypophysectomized adult rats. Acta. endocr., 72, I37-155.

Welschen R., Osman P., Dullaart J., de Greef W. J., Uilenbroek J. Th. J., de Jong F. H., 1975. Levels of follicle-stimulating hormone, luteinizing hormone, oestradiol- $17 \beta$ and progesterone. and follicular growth in the pseudopregnant rat. $J$. Endocr., 64, 37-47. 